\title{
Identifikasi Tingkat Keterampilan Bermain Sepak Bola PS. Taruna Desa Potu Kecamatan Dompu Kabupaten Dompu Tahun 2018
}

\author{
Sandi Achmad Pratama1, Budiman ${ }^{2}$ \\ Dosen Prodi Pendidikan Jasmani Kesehatan Rekreasi STKIP Yapis Dompu \\ achmadsandi077@gmail.com
}

\begin{abstract}
; he level of football playing skills is one aspect of technique that is very influential on the ability of a soccer player in a match. The technical aspects consist of the technique of tilting the ball, passing and holding the ball, heading the ball and shooting towards the goal.This study aims to determine "To what extent are the Skill Levels owned by Taruna Dompu PS players in 2018". Based on the results of data analysis, it was found that from the 25 players who were subjected to the study, it was found that the average score of the players was 57.87 with enough categories, with the following details that included in the good category were 13 people (52\%), moderate categories were 7 people $(28 \%)$, enough categories as many as 4 people (16\%), and less categories as much as 1 person (4\%).Furthermore, when viewed from the average score for each player, the highest score is a heading with an average score of 4 (four) test items of 68.5, while the lowest score is obtained from passing with an average number of scores of 44.75. So clearly based on the data above the level of football playing skills possessed by PS players. Potu Village Cadet Dompu District Dompu Regency in 2018, is still lacking and uneven.
\end{abstract}

\section{Keyword: Identify, Storey, Level Skill, Football}

Abstrak; Tingkat keterampilan bermain sepak bola merupakan satu aspek teknik yang yang sangat berpengaruh terhadap kemampuan seorang pemain sepak bola dalam pertandingan yang dilakukan.Aspek teknik tersebut terdiri dari teknik menggiriing bola, mengoper dan menahan bola, menyundul bola dan menembak ke arah gawang.Penelitian ini bertujuan untuk mengetahui" Sampai sejauh mana Tingkat Keterampilan yang dimiliki para pemain PS. Taruna Desa Potu Kecamatan Dompu Kabupaten Dompu tahun 2018".Berdasarkan hasil analisis data ditemukan bahwa dari Dari 25 pemain yang dijadikan subyek penelitian, didapatkan skor rata-rata pemain adalah 57,87 dengan kategori cukup, dengan perincian sebagai berikut bahwa yang termasuk dalam kategori baik sebanyak 13 orang (52\%), kategori sedang sebanyak 7 orang (28\%), kategori cukup sebanyak 4 orang (16\%), dan kategori kurang sebanyak 1 orang ( $4 \%$ ). Selanjutnya jika ditinjau dari hasil ratarata skor untuk setiap pemainnya, maka skor yang tertinggi adalah heading dengan jumlah skor rata-rata dari 4 (empat) item tes sebesar 68,5, sedangkan skor terendah diperoleh dari passing dengan jumlah skor rata-rata sebesar 44,75 . Jadi jelas berdasarkan data di atas tingkat keterampilan bermain sepak bola yang dimiliki oleh para pemain PS. TarunaDesa Potu Kecamatan Dompu Kabupaten Dompu tahun 2018, masih kurang dan belum merata.

Kata kunci: Identifikasi, Tingkat, Ketermpilan Level, Sepak Bola 


\section{PENDAHULUAN}

Permainan sepakbola modern pertama kali diperkenalkan oleh Cambridge University di Inggris pada tahun 1846, dengan dibuatnya peraturan permainan sepakbola terdiri dari 11 pasal. Peraturan-peraturan itu kemudian disosialisasikan dan dapat diterima oleh universitas dan sekolah lain dan dikenal dengan nama "Cambridge Rules of Football". Selanjutnya pada tanggal 8 Desember 1863 tersusunlah suatu peraturan permainan sepakbola oleh The Football Assosiation dan lahirlah peraturan permainan sepakbola yang digunakan sampai sekarang. Pada tanggal 21 Mei 1904 berdirilah federasi sepak bola dengan nama "FederasiInternationale de Football Assosiation" disingkat FIFA, atas inisiatif RobertGuirin dari Perancis dan sekaligus sebagai ketua yang pertama. Federasi tersebut baru beranggotakan 7 negara pada waktu itu, yaitu :Spanyol, Perancis, Belgia, Belanda, Swiss, Demark, dan Swedia)Persepakbolaan Indonesia saat ini juga sudah mengalami perbaikan,hal yang menandai bangkitnya sepakbola di Indonesia yaitu adanya pembibitan atau adanya pembinaan usia dini dimana pemain muda tersebut dilatih dalam suatu pelatihan yang sekarang dikenal dengan nama SSB atau Sekolah Sepakbola. Ditambah lagi dengan adanya kompetisi dibawah senior yaitu U-12 atau Liga Milo, U-15 atau Bogasari, U-18 atau Piala Suratin, sehingga menambah minat dan motivasi pada pemain belia untuk mengembangkan bakatnya. Di jenjang senior digelar berbagai kompetisi seperti : kompetisi divisi Utama yang merupakan gabungan antara kompetisi perserikatan dan kompetisi Galatama, dan juga Divisi I Nasional dan Divisi II Nasional.

Berdasarkan uraian di atas, maka rumusan masalah yang diajukan dalam penelitian adalah Bagaimanakah tingkat keterampilan bermain sepak bola pada PS. Taruna Desa Potu Kecamatan Dompu Kabupaten Dompu tahun 2018. Hipotesa (hypotesis) berasal dari kata Hipo (hypo) artinya di bawah, kurang, lemah dan thesa artinya kebenaran. Jadi yang dimaksud dengan Hipotesis adalah pernyataan yang masih lemah kebenarannya. Untuk mengemukakan pengertian hipotesis seperti yang dijelaskan oleh penulis sebagai berikut: Hipotesis adalah jawaban sementara terhadap penelitian, yang sebenarnya masih harus diuji secara empiris Sedangkan pendapat lain mengatakan Hipotesis adalah suatu jawaban yang bersifat 17 sementara terhadap permasalahan penelitian sampai terbukti kebenarannya (Dari kedua pendapat para ahli tersebut, maka yang dimaksud dengan hipotesis adalah "pernyataan atau jawaban yang bersifat sementara dari permasalahan penelitian yang perlu pembuktian.Ada dua macam hipotesis yaitu : Hipotesis kerja (Ha) yaitu hipotesis yang menyatakan adanya hubungan antara dua variabel.Hipotesis nol (Ho) yaitu hipotesis yang menyatakan tidak adanyahubungan atau tidak adanya pengaruh antara dua variabel Sehubungan dengan penelitian ini, maka hipotesis yang diajukan adalah sebagai berikut tingkat keterampilan bermain sepak bola pada PS. Taruna Desa Potu Kecamatan Dompu ,Kab.Dompu tahun 2018, berada dalam kategori Baik

\section{METODE PENELITIAN}

Penelitian ini bersifat penelitian ex post facto yang lebih menunjuk kepada perlakuan atau manipulasi variabel bebas (Tingkat Kesegaran Jasmani) yang telah terjadi sebelumnya, sehingga peneliti tidak perlu memberikan perlakuan lagi, tinggal melihat efeknya terhadap variabel yang dalam penelitian ini adalah prestasi belajar. apabila peneliti bermaksud mengetahui keadaan sesuatu mengenai apa dan bagaimana, berapa banyak, sejauh mana dan sebagainya, maka penelitiannya bersifat deskriptif. Sedangkan Rancangan penelitian dapat diartikan sebagai strategi yang mengatur tentang tujuan penelitian, yang pada dasarnya merupakan keseluruhan proses pemikiran dan penentuan matang tentang hal-hal yang akan diteliti. 
Mengingat penelitian yang digunakan dalam penelitian ini adalah penelitian dengan mneggunakan metode expo facto, maka rancangan penelitian yang digunakan " Oneshot case studi". Kepada suatu kelompok diberikan perlakuan kemudian dilakukan pengukuran yang hasilnya memberikan informasi deskriftif, jadi tidak ada kesimpulan yang bersifat imperis (mengesahkan) dari peneliti yang berarti pengambilan data yang dilakukan hanya satu kali.

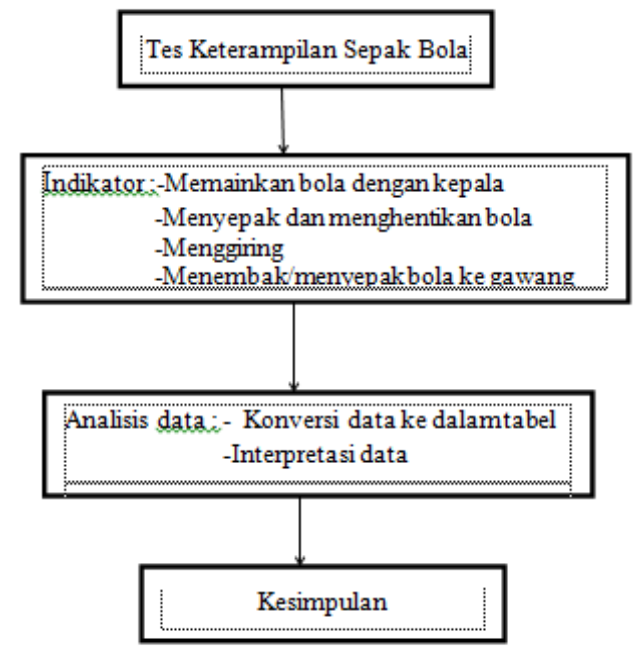

Populasi adalah "sekelompok individu tertentu yang memiliki satu atau lebih karakteristik umum yang menjadi pusat perhatian".Berdasarkan pendapat tersebut di atas, dalam penelitian ini penulis mengambil kesimpulan bahwa populasi dalam penelitian ini adalah seluruh pemain sepak bola PS. Taruna, yang berjumlah 25 pemain. Sampel adalah sebagian atau wakil dari populasi yang diteliti .Selanjutnya pengambilan sampel menurut pendapat lain mengatakan bahwa sampel adalah bagian dari populasi, sebagai contoh yang diambil dengan cara tertentu. Jadi sampel dalam penelitian ini peneliti tidak menggunakan sampel tapi studi populasi. Insrumen ini juga menggunakan Battery Test terdiri dari 3 (tiga) macam item yaitu : Memainkan bola dengan kepala (heading) Menyepak dan menghentikan bola (Passing and stopping) Menggiring bola (dribbel). Jurnal Ilmu Sosial dan Pendidikan
Menembak/menyepak bola kesasaran/gawang (shooting) (Adapun alat-alat penunjang instrumen penelitian tersebut adalah sebagai berikut : Bola sepak ,Stop watch,Sepuluh buah pancang Dinding, Lapangan sepak bola, Blanko penilaian dan Pluit.

Diagram Menggiring Bola (Dribbling)

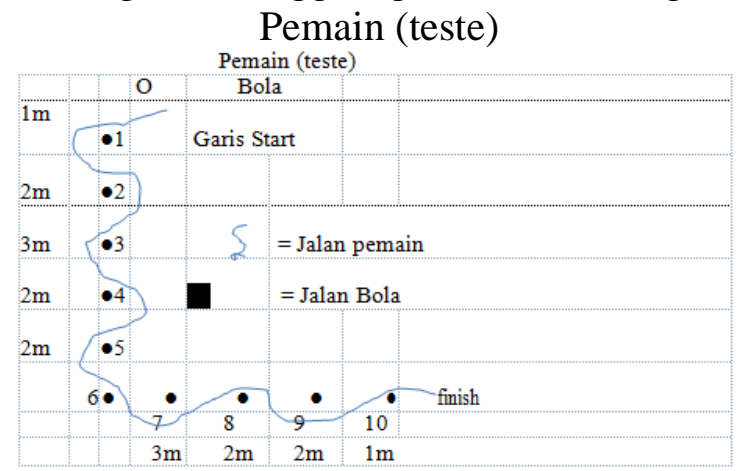

Permulaan menggiring bola tanpa abaaba,pada saat bol menyentuh garis star yang terdapat pada rintangan 1, stopwatch dihidupkan,selanjutnya pemain menggiring bola sesuai dengan arah garis,pada rintangan 3 , bola harus lewat sebelah kanan rintangan dan pemain sebelah kiri,pada rintangan 6 , bola lewat sebelah kiri rintangan selanjutnya mengikuti arah garis sampai bola sampai finish,finish terletak di akhir, bersama itu stopwatch dimatikan,salah jalan selama melakukan dribbling/menggiring harus diperbaiki dan selama itu stopwatch hidup terus waktu yang dicatat adalah waktu yang dicapai dari permukaan sampai bola dan pemain telah melewati finish.Metode Dokumentasi dalam penelitian ini digunakan sebagai penunjang dalam pengumpulan data. Dan untuk metode documenter ini adalah teknik lain yang digunakan oleh para penyelidik dalam suatu penelitian adalah meneliti benda-benda tertulis masa lampau, jadi pencatat dokumen adalah salah satu metode yang digunakan untuk mengumpulkan data yang berupa arsip-arsip pada suatu lembaga atau instansi tertentu,Test adalah perbuatan adalah suatu cara untuk mengadakan penelitian yang berbentuk suatu tugas atau serangkaian yang harus dikerjakan oleh pemain atau sekelompok pemain, sehingga menghasilkan suatu nilai tentang tingkah laku 
atau prestasi pemain tersebut, yang dapat dibandingkan dengan nilai yang dicapai oleh pemain-pemain lain atau dengan nilai standar yang ditetapkan. Dalam penelitian metode analisa data yang digunakan adalah analisis deskriftif dengan cara menentukan klasifikasi pemain berdasarkan skor yang diperoleh dari hasil 4 item tes yang terdiri dari : Tes menggiring bola, Tes menendang dan menghentikan bola,Tes memainkan bola dengan kepala dan Tes menembak bola ke gawang.

\section{HASIL DAN PEMBAHASAN}

\section{A. Hasil Penelitian}

Dalam hal ini penelitian akan membahas segala sesuatu yang berhubungan dengan proses penelitian dalam rangka pembuktian dari permasalahan yang tercantum persiapan peneliti, jalannya peneliti, jadwal kegiatan serta data-data yang berhubungan dengan penelitian Sedangkan jadwal pelaksanaan penelitian pada club Ps Taruna:

\begin{tabular}{|c|c|c|c|c|}
\hline No & Kegiatan & Hari/tanggal & Waktu & Tempat \\
\hline 1 & 2 & 3 & 4 & 5 \\
\hline 1 & $\begin{array}{l}\text { Pengambilan data pemain } \\
\text { (nama dan umur) }\end{array}$ & $\begin{array}{l}\text { Senin ,20 Agustus } \\
2018\end{array}$ & 08.00-Selesai & $\begin{array}{l}\text { Sekretariat club } \\
\text { Ps. Taruna }\end{array}$ \\
\hline 1 & 2 & 3 & 4 & 5 \\
\hline 2 & $\begin{array}{l}\text { Pengambilan heading dan } \\
\text { passing }\end{array}$ & $\begin{array}{l}\text { Selasa,21 Agustus } \\
2018\end{array}$ & 16.00 -Selesai & $\begin{array}{l}\text { Lapangan GOR } \\
\text { Dompu }\end{array}$ \\
\hline 3 & $\begin{array}{l}\text { Pengambilan data dribbling } \\
\text { dan shooting }\end{array}$ & $\begin{array}{l}\text { Senin ,27 Agustus } \\
2018\end{array}$ & 16.00-Selesai & $\begin{array}{l}\text { Lapangan GOR } \\
\text { Dompu }\end{array}$ \\
\hline
\end{tabular}

Pelaksanaan penelitian meliputi penentuan sampel Seperti sudah di jelaskan bahwa populasi dalampenelitian ini adalah para pemain sepak bola pada klub PS. Taruna Desa Potu Kec. Dompu Kabupaten Dompu yang berjumlah 25 orang. Adapun data nama-nama pemain adalah sebagai berikut:
Tabel 1

\begin{tabular}{|c|c|c|c|}
\hline No & Nama & Umur & Posisi \\
\hline $\mathbf{1}$ & $\mathbf{2}$ & $\mathbf{3}$ & $\mathbf{4}$ \\
\hline 1 & Deni & 24 & Bek kanan \\
\hline 2 & Dian & 23 & Bek kiri \\
\hline 3 & Sira & 22 & Gelandang \\
\hline 4 & Daus & 24 & Penyerang \\
\hline 5 & Junaidin & 26 & Penyerang \\
\hline 6 & Jiyat & 29 & Bek tengah \\
\hline 7 & Rian & 23 & Bek tengah \\
\hline 8 & Murdani & 25 & Geladang tengah \\
\hline 9 & Jamaludin & 22 & Sayap kiri \\
\hline 10 & Edwiansah & 24 & Bek kanan \\
\hline 11 & Saiful & 21 & Sayap kiri \\
\hline 12 & Yadin & 22 & Sayap kanan \\
\hline 13 & Maman & 22 & Geladang kiri \\
\hline 14 & Cipto & 27 & Sayap kiri \\
\hline 15 & Didi & 24 & Penjaga gawang \\
\hline 16 & Faisal & 25 & Bek tengah \\
\hline 17 & Dimas & 23 & Penyerang \\
\hline 18 & Rizal & 20 & Gelandang \\
\hline 19 & Sadam & 19 & Sayap kanan \\
\hline 20 & Budiman & 18 & Bek kiri \\
\hline 21 & Iwan & 22 & Gelandang \\
\hline 22 & Putra & 24 & Penyerang \\
\hline 23 & Farid & 26 & Sayap kiri \\
\hline 24 & Bagas & 24 & Bek \\
\hline 25 & Huda & Penyerang \\
\hline
\end{tabular}

Pelaksanaan Test dari ke 4 item tersebut ialah Memainkan bola dengan kepala Pada abaaba "siap" pemain berdiri menghadap tembok dengan bola di tangan Pada aba-aba "ya" bola dipantulkan ketembok dan selanjutnya dimainkan dengan kepala sebanyak-banyaknya selama 10 detik. Skor dihitung sebanyak bola yang dimainkan dengan kepala dan mengenai garis batas $2 \mathrm{~m}$ atau di ataugaris tersebut selama 10 detik Menyepak dan menghentikan bola (passing dan stop bola) Aba-aba permulaan tidak diberikan. Pada saat bola disepak dari belakang garis batas 3 meter, stop watch dihidupkan.Bola yang memantul dari dinding harus ditahan/dihentikan terlebih dahulu di belakang garis sebelum di sepak ke dinding lagi. Apabila bola memantul jauh dari dinding maka bola tersebut harus diambil oleh pemain yang bersangkutan dan selanjutnya memainkan bola seperti semula, sampai aba-aba "stop" diberikan. Kegiatan ini dilakukan selama 10 detik, skor yang dihitung ialah jumlah sepakan dan menghentikan bola dari belakang garis 3 meter selama 10 detik.. Menggiring Bola (Dribbling) Pada saat bola menyentuh garis start yang terdapat pada rintangan 1 stop watch di hidupkan. Selanjutnya pemain menggiring bola sesuai dengan arah panah.Pada rintangan ketiga, bola diharuskan lewat sebelah kiri rintangan dan pemain harus lewat sebelah kanan, selanjutnya mengikuti arah panah. Pada 
rintangan keempat bola harus dilewatkan sebelah kanan rintangan dan pemain harus lewat sebelah kiri rintangan, selanjutnya mengikuti arah panah sampai bola tersebut melewati garis finish. Garis finish terletak pada rintangan terakhir, bersamaan dengan itu stop watch dimatikan. Salah jalan selama melakukan dribbling harus diperbaiki dimana terjadinya pelanggaran dan selama itu stop watch harus tetap hidup. Waktu yang dicatat adalah waktu yang dicapai dari permulaan sampai bola dan pemain melewati garis finish. Menembak/ menendang ke sasaran (shooting) Bola diletakkan pada sebuah titik 13 meter dari gawang tepat pertengahan gawang. Waktu tembakan yang di ambil pada saat kaki menembak mengenai bola sampai mengenai tembok/gawang.Skor tembakan, angka pada gawang yang di kenakan oleh bola.Bila bola mengenai garis antara kotak didalam gawang yang tertinggi yang di catat sebagai skor.

Tabel 2. Data hasil tes keterampilan sepak bola pemain PS. Taruna Desa Potu Kecamatan Dompu Kab. Dompu tahun 2018.

\begin{tabular}{|c|c|c|c|c|c|c|c|c|c|c|}
\hline No & \multicolumn{2}{|c|}{ Heading } & \multicolumn{2}{|c|}{ Passing } & \multicolumn{2}{|c|}{\begin{tabular}{|l|} 
Dribbling \\
\end{tabular}} & \multicolumn{4}{|c|}{ Shooting } \\
\hline & Nilai & Skor & \begin{tabular}{|l} 
Nilai \\
\end{tabular} & Skor & Waku & Skor & waktu & skor & nilai & skor \\
\hline 1 & 2 & 3 & 4 & 5 & 6 & 7 & 8 & 9 & 10 & 11 \\
\hline 1 & 5 & 76 & 5 & 66 & $11^{\prime}, 00^{\prime \prime}$ & 73 & $0,56 "$ & 74 & 2 & 53 \\
\hline 2 & 5 & 76 & 3 & 50 & $12^{\prime}, 25^{\prime \prime}$ & 69 & $0 ; 78^{\prime \prime}$ & 68 & 3 & 58 \\
\hline 3 & 3 & 61 & 3 & 50 & $13^{\prime}, 60^{\prime \prime}$ & 68 & $0,91 "$ & 58 & 2 & 53 \\
\hline 4 & 3 & 61 & 4 & 58 & $10^{\prime}, 75^{\prime \prime}$ & 74 & $0,58 "$ & 74 & 1 & 47 \\
\hline 5 & 5 & 76 & 5 & 66 & $13^{\prime}, 56^{\prime \prime}$ & 68 & $0 ; 70 "$ & 66 & 3 & 58 \\
\hline 6 & 3 & 61 & 3 & 50 & $14^{\prime}, 25^{\prime \prime}$ & 66 & $0,50 "$ & 74 & 3 & 58 \\
\hline 7 & 2 & 54 & 4 & 58 & $14^{\prime}, 88^{\prime \prime}$ & 64 & $0: 97 "$ & 61 & 1 & 47 \\
\hline 8 & 4 & 68 & 4 & 58 & $13^{\prime}, 57^{\prime \prime}$ & 68 & 0;8" & 65 & 4 & 63 \\
\hline 9 & 3 & 61 & 3 & 50 & $12^{\prime}, 64^{\prime \prime}$ & 70 & $0 ;, 83^{\prime \prime}$ & 63 & 5 & 68 \\
\hline 10 & 3 & 61 & 4 & 58 & $11^{\prime}, 71^{\prime \prime}$ & 72 & $0 ; 93 "$ & 59 & 4 & 63 \\
\hline 11 & 4 & 68 & 3 & 50 & $12^{\prime}, 97^{\prime \prime}$ & 70 & $0^{\prime}, 84^{\prime \prime}$ & 63 & 2 & 53 \\
\hline 12 & 5 & 76 & 2 & 42 & $16^{\prime} .54^{\prime \prime}$ & 62 & $0,50^{\prime \prime}$ & 74 & 5 & 68 \\
\hline 13 & 5 & 76 & 5 & 66 & $13^{\prime}, 53^{\prime \prime}$ & 68 & $0^{\prime}, 66^{\prime \prime}$ & 70 & 3 & 58 \\
\hline 14 & 6 & 83 & 4 & 58 & $15^{\prime}, 66^{\prime \prime}$ & 64 & $0,91 "$ & 58 & 5 & 68 \\
\hline 15 & 4 & 68 & 4 & 58 & $12: 20 "$ & 69 & $1,10^{\prime \prime}$ & 50 & 3 & 58 \\
\hline 16 & 5 & 76 & 3 & 50 & 13',94" & 68 & $0,88^{\prime \prime}$ & 65 & 5 & 68 \\
\hline 17 & 4 & 68 & 4 & 58 & $15^{\prime}, 15^{\prime \prime}$ & 66 & $0,87^{\prime \prime}$ & 64 & 4 & 63 \\
\hline 18 & 5 & 76 & 3 & 50 & $10^{\prime}, 94^{\prime \prime}$ & 74 & $0^{\prime}, 78^{\prime \prime}$ & 68 & 2 & 53 \\
\hline 19 & 3 & 61 & 3 & 50 & $14^{\prime}, 42^{\prime \prime}$ & 66 & 0:91" & 58 & 3 & 58 \\
\hline 20 & 4 & 68 & 3 & 50 & $15^{\prime}, 59^{\prime \prime}$ & 64 & $0 ; 75^{\prime \prime}$ & 67 & 2 & 53 \\
\hline 21 & 5 & 76 & 4 & 58 & $13^{\prime}, 72^{\prime \prime}$ & 67 & 0',90" & 58 & 2 & 53 \\
\hline 22 & 5 & 76 & 4 & 58 & $14^{\prime}, 35^{\prime \prime}$ & 66 & $0: 97 "$ & 61 & 2 & 53 \\
\hline 23 & 5 & 76 & 3 & 50 & $11^{\prime}, 59^{\prime \prime}$ & 72 & $0.91 "$ & 58 & 3 & 58 \\
\hline 24 & 4 & 68 & 4 & 58 & $14^{\prime}, 72^{\prime \prime}$ & 65 & $0,68 "$ & 70 & 4 & 63 \\
\hline 25 & 5 & 76 & 3 & 50 & $13^{\prime}, 72^{\prime \prime}$ & 67 & $0,90^{\prime \prime}$ & 58 & 3 & 58 \\
\hline
\end{tabular}

TABEL 3 :Data skor T dari hasil tes keterampilan sepak bola pemain PS.Taruna Desa potu kecamatan Dompu Kabupaten Dompu tahun 2018

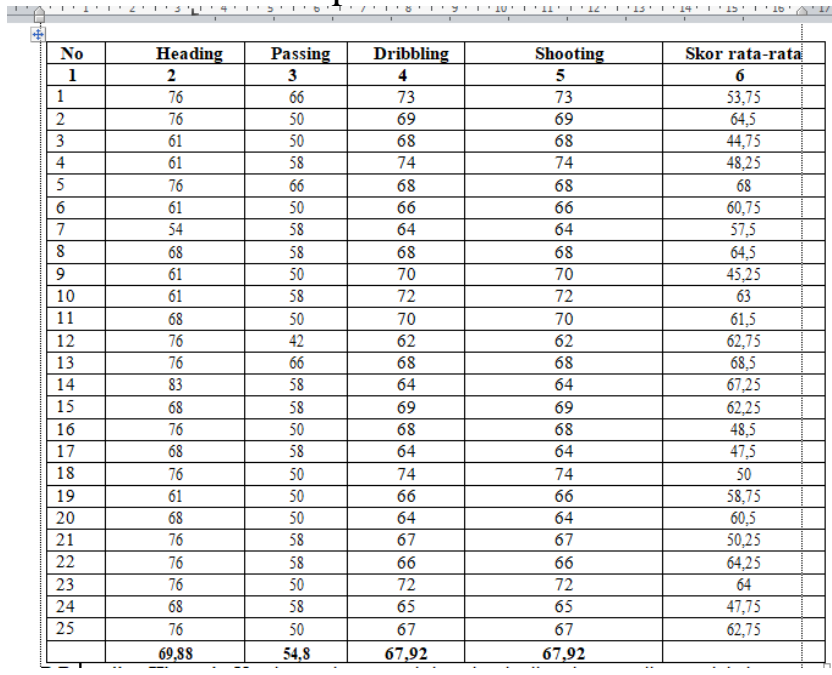

\section{B. Pengujian Hipotesis}

Untuk menginterpretasi data-data hasil tes keterampilan sepak bola yang diperoleh para pemain PS. Taruna Desa Potu Kecamatan Dompu Kab. Dompu tahun 2018, digunakan skala prestasi dalam bentuk T-skor sebagai berikut:

Tabel 4 : kategori skala prestasi dari hasil tes tskor tes keterampilanbermain sepak bola

\begin{tabular}{|c|c|}
\hline KATEGORI & SKALA \\
\hline BAIK SEKALI & 81-Ke atas \\
\hline BAIK & $61-80$ \\
\hline CUKUP & $53-60$ \\
\hline SEDANG & $46-52$ \\
\hline KURANG & $37-45$ \\
\hline BURUK & 36 Kebawah \\
\hline
\end{tabular}

Selanjutnya dari hasil interprestasi data berdasarkan skala prestasi dalam bentuk t skor, maka ditentukan kategori prestasi pemain PS. Putra Kembang Desa Aik Darek Kecamatan Batukliang Kab.Lombok Tengah tahun 2011 berdasarkan jumlah skor skor rata-rata yang diperoleh dari hasil tes keterampilan bermain sepak bola.Adapun kategori yang tergabung dalam PS. Taruna Desa Potu Kecamatan Dompu Kab. Dompu tahun 2018 tersebut dapat dilihat pada tabel berikut:

Tabel 5 : Kategori prestasi pemain PS. Taruna Desa Potu Kecamatan Dompu Kab. Dompu 
tahun 2018.Berdasarkan jumlah skor rata-rata dari hasil tes keterampilan bermain sepak bola.

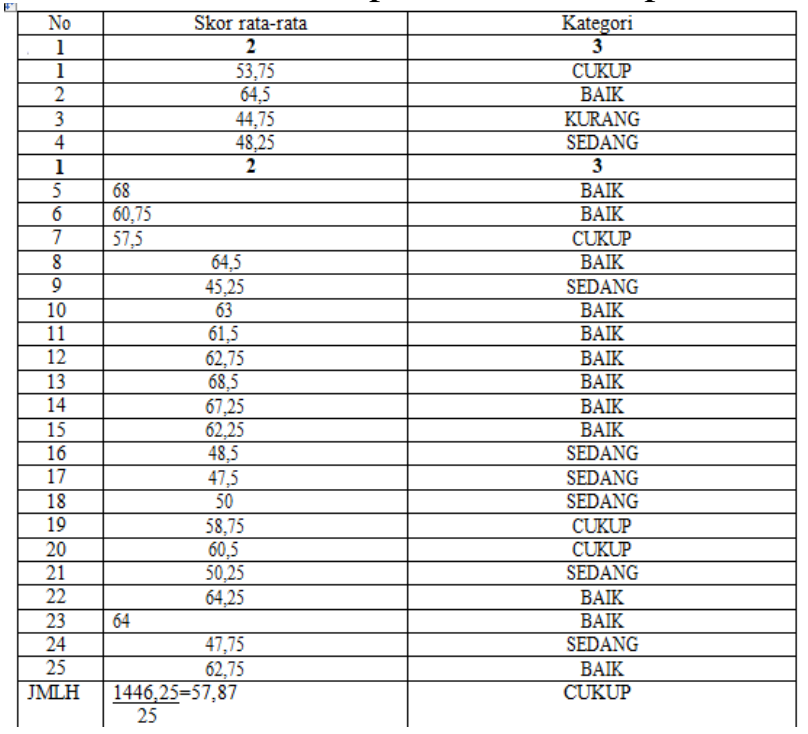

\section{PEMBAHASAN}

Identifikasi tentang kemampuan para pemain sepak bola sangat penting bagi seorang pelatih untuk mengetahui sampai sejauh mana tingkat kemampuan bermain sepak bola yang dimiliki oleh para pemainnya. Selanjutnya dengan berpedoman pada kemampuan para pemainnya, pelatih dapat menyiapkan program latihan yang sesuai dengan keterampilan yang berhubungan dengan metode maupun frekuensi latihan yang diberikan.Dengan demikian sangat perlu adanya usaha guna membantu pemain dalam mengatasi masalah yang dialaminya dengan maksud untuk meningkatkan prestasi dalam cabang olahraga sepak bola. Salah satu bentuk yang bisa diberikan adalah latihan secara continue sesuai dengan program latihan yang telah ditentukan guna mencapai prestasi yang maksimal.Dari hasil penelitian yang dilakukan oleh peneliti dari 25 pemain PS. Taruna Taruna Desa Potu Kecamatan Dompu Kab. Dompu tahun 2018 tersebut, dari seluruh jumlah pemain yang menjadi subyek penelitian, diketahui hasil skor rata-rata pemainnya adalah 57,87 dengan kategori Cukup, dengan perincian sebagai berikut bahwa yang termasuk dalam kategori baik sebanyak 13 orang (52 \%), kategori sedang sebanyak 7 orang (28 \%), kategori cukup sebanyak 4 orang (16\%), dan kategori kurang sebanyak 1 orang (4\%).Apabila titinjau dari 4 item tes yang digunakan untuk mengetahui tingkat kemampuan bermain sepak bola para subyek penelitian, maka teknik dasar yang memperoleh skor tertinggi adalah heading (memainkan bola dengan kepala) dengan skor rata-rata tiap pemain sebesar 68,5 sedangkan skor rata-rata tiap pemain sebesar 44,75.Demikian program latihan yang disiapkan oleh pelatih terutama ditujukan untuk meningkatkan teknik passing (menyepak dan menghentikan bola), tetapi dengan demikian bukan berarti teknik dasar yang lain tidak mendapatkan perhatian untuk lebih di tingkatkan.Selanjutnya jika ditinjau dari hasil rata-rata skor untuk setiap pemainnya, maka skor yang tertinggi adalah subyek dengan nomor 1 (satu) dengan jumlah skor rata-rata dari 4 (empat) item tes sebesar 68,5, sedangkan skor terendah diperoleh subyek dengan nomor 3 (tiga) dengan jumlah skor rata-rata sebesar 44,75 .

\section{KESIMPULAN}

Berdasarkan hasil analisis data yang diperoleh melalui 4 macam item tes keterampilan bermain sepak bola yang terdiri dari tes menggiring bola, mengoper bola, dan menghentikan bola, menyundul bola dan menembak bola ke gawang terhadap para pemain yang tergabung sebagai pemain PS. TarunaDesa Potu Kec. Dompu Kabupaten Dompu tahun 2018, dapat disimpulkan hal-hal sebagai berikut:Dari 25 pemain yang dijadikan subyek penelitian, diketahui bahwa nilai skor rata-rata para pemain adalah 57,87, dengan kategori cukup dengan rincian sebagai berikut, yang termasuk dalam kategori baik sebanyak 13 orang (52 \%), kategori sedang sebanyak 7 orang (28\%), kategori cukup sebanyak 4 orang (16\%), dan kategori kurang sebanyak 1 orang (45).Ditinjau dari hasil rata-rata skor untuk setiap pemainnya, maka skor yang tertinggi adalah subyek dengan nomor 1 (satu) dengan jumlah skor rata-rata dari 4 (empat) item tes sebesar 68,5, sedangkan skor terandah diperoleh subyek dengan nomor 3 (tiga) dengan 
jumlah skor rata-rata sebesar 44,75. Hasil tes tersebut telah membuktikan bahwa penelitian yang dilakukan kepada para pemain PS. Putra Kembang sangat positif terhadap perkembangan sepak bola di Kec.Batukliang khususnya dan di Lombok Tengah pada umumnya.

SARAN

Berdasarkan pengamatan peneliti selama mengadakan penelitian dan dari hasil analisis data, maka peneliti mengajukan saransaran, baik kepada para Pelatih, Pembina maupun para pemain PS. Taruna Kecamatan Dompu Kabupaten Dompu untuk: Merancang program latihan yang baik dengan memperhatikan prinsip-prinsip latihan yang benar: a)Jumlah latihan dalam perminggunya ditamah agar teknik, taktik dan tehnik selalu bertambah. b)Istirahat dan makan yang cukup pada saat latihan maupun dirumah untuk dapat menjaga kondisinya.Manfaatkan hasil penelitian ini sebagai motivasi berpretasi para pemian PS.Taruna Kecamatan Dompu Kabupaten Dompu untuk berupaya terus meninggkatkan prestasi yang telah diraih selama ini. Menyiapkan alat dan fasilitas yang lebih baik dalam menunjang proses latihan agar tujuan latihan dapat dicapai secara optimal.

\section{UCAPAN TERIMA KASIH}

Alhamdulillah puji syukur kepada Allah SWT, karena kehendak dan ridhaNya peneliti dapat menyelesaikan penelitian ini rasa syukur dorongan dari istri tercinta yang selalu mendukung dan memberikan motivasi serta terima kasih kepada pemilik club Ps Taruna.

\section{DAFTAR PUSTAKA}

Agus salim, (2008) "Buku Pintar Sepak bola" Bandung: Nuansa.

Dani mielke,(2007) "Dasar-dasar sepak bola" Bandung:Pakar Raya

Eri setiyono ,2009) "Perbedaan tingkat kecepatan dribbling pemain depan dan belakang dalam permainan sepak bola".

Riduwan. 2004. Metode Riset. Jakarta : Rineka Cipta.
Sucipto ,(2000), dkk.”Sepak bola” Departemen pendidikan dan kebudayaan

Sugiyono (2006)."Statitiska untuk penelitian". Bandung: Alfabeta.

Sujana, Nana, dan Ibrahim. 2001. Penelitian dan Penilaian Pendidikan. Bandung. Sinar Baru Algesindo

Sukatamsi,(2001) "Tehnik dasar bermain sepak bola". Surakarta: Tiga serangkai 